\title{
ENTREPRENEURSHIP MANAGEMENT AT PRIMARY SCHOOL
}

\section{Nur Indah Lailya Mawar Sari, Syahrul Nursianawati}

Universitas Sebelas Maret

nursianawati@gmail.com

\section{Article History}

accepted 09/07/2018

approved 01/08/2018

published 17/09/2018

\section{Keywords}

Management,

Entrepreneurship, Primary

School

\begin{abstract}
This article aims to describe the importance of entrepreneurship at primary schools. This form of research is descriptive qualitative. Data collection using observation sheets and interviews. The data obtained were collected and processed using qualitative analysis techniques. the results of this study indicate that the need for entrepreneurial management in primary schools to create independent and creative schoolchildren. In entrepreneurship atprimary schools it is necessary to work together for the achievement of goals. The development of entrepreneurship management needs to perform the functions of planning, organizing, implementing, and controlling or supervising.
\end{abstract}

Social, Humanities, and Education Studies (SHEs): Conference Series

p-ISSN 2620-9284 https://jurnal.uns.ac.id/shes e-ISSN 2620-9292 


\section{PENDAHULUAN}

Pendidikan sebagai pilar atau sentral utama berdirinya suatu negara atau bangsa yang membentuk kualitas sumber daya manusia. Pendidikan masyarakat yang saat ini dilaksanakan hanya berorientasi pada penguatan materi kognitif pengetahuan, akibat yang ditimbulkan dari budaya pendidikan tersebut adalah pembentukan karakter peserta didik yang pasif, bermental perintah (mengerjakan sesuatu harus dengan perintah) dan akhirnya lulus dari jenjang pendidikan berorientasi menjadi pegawai. Menurut Undang-Undang No. 20 Tahun 2003,pendidikan adalah usaha sadar dan terencana untuk mewujudkan suasana belajar dan proses pembelajaran agar peserta didik secara aktif mengembangkan potensi dirinya untuk memiliki kekuatan spiritual keagamaan, pengendalian diri, kepribadian, kecerdasan, akhlak mulia, serta ketrampilan yang diperlukan dirinya, masyarakat, bangsa dan negara. Sesuai dengan tujuan pendidikan menciptakan sumber daya manusia yang berkualitas, cerdas dan berdaya saing kuat sesuai perkembangan zaman.

Melalui kebijakan Departemen Pendidikan Nasional yang memasukkan kurikulum pendidikan kewirausahaan di lembaga pedidikan (Depdiknas, 2013). Konsep kewirausahaan terintegrasi sejak anak didik duduk di bangku sekolah dasar hingga perguruan tinggi. Pendidikan kewirausahaan membekali peserta didik untuk mandiri dan tidak berorientasi menjadi pencari kerja melainkan pembuka lapangan pekerjaan. Kewirausahaan pada hakikatnya adalah suatu sikap, jiwa dan kemampuan untuk menciptakan sesuatu yang baru dan bernilai serta berguna bagi diri dan orang lain. Kewirausahaan muncul apabila seseorang berani mengembangkan usaha-usaha dan ide-ide baru. Dalam jiwa kewirausahaan tertanam jiwa yang selalu aktif, kreatif, berkarya dan inovatif untuk meningkatkan pendapatan dalam usahanya.

Sedangkan Drucker (1985) mengartikan kewirausahaan sebagai semangat, kemampuan, sikap, perilaku individu dalam menangani usaha/kegiatan yang mengarah pada upaya mencari, menciptakan, menerapkan cara kerja, teknologi, dan produk baru dengan meningkatkan efisiensi dalam rangka memberikan pelayanan yang lebih baik dan atau memperoleh keuntungan yang lebih besar. menurut

MenurutDeandan sharfman (1996) The Whole Curriculum suggests that it should involve helping students make decisions about such things as how to organise their finances and making them aware of government economic policy and the impact of economic policy on the environment. It a Iso suggests that students need to understand enterprise and wealth creation and develop entrepreneurial skills.

Berdasarkan observasi di SDN 01 Nangsri Kebakkramat menunjukkan bahwa di SDN 01 Nangsri Kebakkramat menjadikan program kewirausahaan menjadi bagian dari kurikulum sekolah tersebut. Adapun kewirausahaan yang berada di SDN tersebut yaitu, penyewaan kantin, koperasi, kerajinan tangan, bercocok tanam atau berkebun. Dalam mengembangankan kewirausahaan diperlukan kecerdasan-kecerdasan agar kewirausahaan dapat berkembang degan baik dan mempunyai income pada suatu organisasi.Pada lingkungan sekolah diperlukan kecerdasan yang handal agar dapat memberikan kontribusi yang positif dan dapat tercapainya tujuan wirausaha tersebut salah satunya yaitu dengan diperlukannya kecerdasan kecerdasan Finansial (FQ), Kecerdasan Intelektual (IQ), Kecerdasan Emosional (EQ), Spiritual Quotient (Kecerdasan Spiritual), dan Kecerdasan Advertisy (AQ). Kecerdasan-kecerdasan ini dapat memberikan kontribusi dalam kewirausahaan yang berada di lingkup terutama pada lingkup sekolah dasar.

Berdasarkan permasalahan di atas maka rumusan masalah dalam penelitian ini akan disebutkan sebagai berikut, bagaimana manajemen pengembangan kewirausahaan di SDN 01 Nangsri Kebakkramat?, apa hambatan dalam melakukan manajemen kewirausahaan di SDN 01 Nangsri Kebakkramat?, bagaimana solusi melakukan manajemen kewirausahaan di SDN 01 Nangsri Kebakkramat? 
Berdasarkan rumusan masalah, maka tujuan penelitian yang hendak dicapai adalah untuk mengetahui manajemen pengembangan kewirausahaan di SDN 01 nangsri Kebakkramat, untuk menegtahui hambatan manajemen pengembangan kewirausahaan di SDN 01 Nangsri Kebakkramat, untuk mengetahui solusi dalam manajemen pengembangan kewirausahaan di SDN 01 Nangsri Kebakkramat.

\section{METODE}

Penelitian ini menggunakan pendekatan kualitatif dengan metode deskriptif. Peneliti melakukan analisis terhadap berbagai data yang ada. Adapun pegumpulan data dilakukan melalui berbagai teknik wawancara dengan kepala sekolah dan observasi di SDN 01 Nangsri Kebakkramat. Untuk lokasi dari penelitian ini adalah SDN 01 Nangsri Kebakkramat. Sedangkan yang menjadi subjek dalam penelitian ini dipilih secara purposive sampling dari pihak yang menjadi sasaran penelitian atau sumber yang dapat memberikan informasi yaitu kepala sekolah SDN 01 Nangsri Kebakkramat yang bernama Warsiti, S.Pd. Teknik analisis data mengacu pada langkah-langkah yang dipakai oleh Miles dan Huberman (2007) yang terdiri dari tiga alur kegiatan yang dilakukan secara bersamaan yaitu reduksi data, penyajian data, dan penarikan kesimpulan/verifikasi.

\section{HASIL DAN PEMBAHASAN}

Berdasarakan wawancara yang dilakukan dengan kepala sekolah diperoleh hasil yang menunjukkan bahwakegiatan kewirausahaan di SDN 01 Nangsri lebih menekankan pada kreativitas siswa dengan menggunakan bahan-bahan yang ramah lingkungan. Karena SDN 01 Nangsri merupakan sekolah rintisan Adiwiyata siswa diajarkan untuk membuat hasil karya yang berbahan ramah lingkungan yang dapat didaur ulang sehingga dapat menghasilkan suatu karya yang dapat diperjual belikan dapat memberikan pemasukan pada peserta didik dan dapat dimanfaatkan sebagai sumber dana untuk mengembangkan karya yang lain sehingga dapat berkembangkan bervariasi. Pada acara-acara adiwiyata biasanya hasil karya sisswa dapat dipamerkan dan diperjual belikan. Hasil-hasil karya siswa selain diperjual belikan di koperasi sekolah juga dipajang di etalase sekolah sebagai bentuk apresiasi kepada siswa.

\section{A. Manajemen Pengembangan Kewirausahaan Di SDN 01 Nangsri}

Menurut Robert (dalam Alma: 2011)Entrepreneur is the processof creating something different with value by devoting the nessary time and effort, assuming the accompanying financial, psychological, and social risks and receiving the resulting rewards of monetary and personal satisfaction.

Sementara itu, menurut Frinces (2011) entrepreneur atau wirausaha adalah orang yang kreatif, dinamis, inovatif, dan dia mau mengambil berbagai resiko dan berani menghadapi semua tantangan yang tidak dapat diprediksi dan diramal sebelumnya, lewat krativitasnya dan kekuatan kemauan (the will power) untuk mencapai sukses.

Berdasarkan beberapa definisi diatas, maka dapat dikatakan bahwa entrepreneur atau wirausaha adalah orang yang menciptakan sesuatu yang kreatif, dinamis inovatif serta mau mengambil resiko dari segi waktu, keuangan, kejiwaan sosial dan menerima balas jasa dalam bentuk uang dan keputusan pribadinya untuk mencapai sukses. 
Untuk kegiatan manajemen pengembangan kewirausahaan di SDN 01 Nangsrimeliputi :

\section{Perencanaan}

Perecanaan merupakan suatu proses penyusunan sesuatu yang akan dilaksanakan untuk mencapai tujuan yang akan ditentukan. perencanaan dapat disusun berdasarkan kebutuhan jangka panjang dan pendek. Perencanaan yang dilakukan SDN 01 Nangsri Kebakkramat yaitu:

a. Pencanaan Kurikulum

Berdasarkan hasil wawancara, dapatdijelaskan bahwa kewirausahaan yang berada di SDN 01 Nangsri termasuk dalam kegiatan ekstrakurikuler.

b. Perencanaan Ekstrakurikuler Kewirausahaan

Pada saat ekstrakurikuler perencanaan dengan mempersiapkan bahan dan alat yang akan digunakan dalam pembelajaran kerajinan tangan, bercocok tanam, koperasi dengan menyiapkan alat-alat yang akan dijual, penataan kantin dengan inovasi-inovasi yang sesuai dengan kemampuan siswa dan warga sekolah dalam penataan kewirausahaan di sekolah.

c. Perencanaan Biaya

Kepala sekolah SDN 01 Nangsri berupaya untuk melakukan pengembangan dalam segi biaya yaitu dengan menggunakan dana BOS untuk operasional penggunaan bahan-bahan dan hasil karya siswa yang telah terjual dapat dikembangkan pada hal yang lain.

\section{Pengorganisasian}

Pengorganisasian merupakan suatu tindakan atau kegiatan menggabungkan seluruh potensi yang ada dari seluruh bagian dalam kelompok orang atau badan organisasi untuk bekerja secara bersama-sama guna mencapai tujuan yang telah ditentukan bersama,baik untuk tujuan pribadi atau tujuan kelompok organisasi.Berdasarkan wawancara, kewirausahaan di SDN 01 Nangsri menerapkan KISS (Koordinasi, Integrasi, Simplikasi, Sinkronisasi, Mekanisasi).

\section{Pelaksanaan}

Pelaksanaan kewirausahaan lebih menekankan praktek daripada teori, sehingga siswa dapat terjun langsung dalam kegiatanwirausaha. Hal ini diperkuat dengan penjelasan Ibu Warsiti, S.Pd, Kewirausahaan yang berada di SDN 01 Nangsri diantaranya:

\section{a. Koperasi Sekolah}

Koperasi sekolah dikelola oleh warga sekolah dengan penangung jawab salah satu guru yaitu ibu Karyani semua warga sekolah saling gotong royong bahu membahu melayani dikoperasi sekolah. Siswa diajarkan untuk jujur hasil sekolah koperasi dapat dikembangkan untuk membeli alat-alat yang lain selain itu koperasi sekolah juga menjual hasil-hasil karya siswa.

b. Membuat Kerajinan Tangan

Dalam membuat kerajinan tangan dipimpin oleh salah seorang guru yaitu ibu Hanif Binar Saputri. Selain ibu hanif binary terdapat piket guru nuntuk berperan serta dalam mendampingi anak-anak untuk membuat karya kerajinan tangan

C. Bercocok tanam

Bercocok tanam di lingkungan SDN 01 Nangsri Kebakramat dapat diikuti oleh seluruh siswa. Siswa membawa tanaman dari rumah yang dan ditanam di sekolahan di lahan kecil Green House. Setiap 2 Hari sekali siswa diwajibkan untuk menyirami tanaman mereka sendiri pada kelas bawah siswa membawa tanaman hias. Sedangkan pada siswa kelas atas membawa tanaman obat dan tanaman sayuran. 


\section{d. Penyewaaan kantin Sekolah}

Dalam penyewaan kantin sekolah. Disewakan pada salah satu warga. Kantin sekolah ini bekerja sama dengan guru untuk menciptakan anak yang sehat sehat, Sehingga makanan yang dijual di kantin sekolah ini mengandung bahan-bahan yang tidak mmebahayakan siswa. Selain itu guru juga berperan dalam membuatkan jajanan untuk diperjual belikan.

\section{Pengendalian atau Pengawasan}

Pengendalian dan pengawasan pelaksanaan kepala sekolah setiap minggu kepala sekolah meninjau kembali kegitan-kegiatan kewirausahaan yang ada di sekolah hal ini selalu dibahas pada saat rapat sekolah yang dilaksanakan pada seminngu sekali. Setiap bidang penangung jawab mewakili menyampaikan pendapat mengenai ketercapaian kewirausahaannnya.

Menurut Samino(2012) Kepala sekolah adalah manajer, dalam manajemen pendidikan terdapat 4 fungsi, yaitu: perencanaan, pengorganisasian, pengarahan atau penggerakan, dan pengendalian atau pengawasan. Hal ini sejalan dengan manajemen kewirausahaan di SDN 01 Nangsri yang meliputi keempat hal tersebut,dan kegiatan kewirausahaannya dimasukan kedalam ekstrakurikuler sekolah seperti membuat kerajinan tangan dan bercocok tanam. Kewirausahaan di SDN 01 Nangsri bertujuan untuk meningkatkan kemandirian dan jiwa untuk berwirausaha bagi warga sekolah dan membekali siswa meningkatkan jiwa kemandirian dan kreatifitas anak. Hal ini terbukti siswa- siswi SDN 01 Nangsri mampu menghasilkan karya-karya buatan yang bagus dan dapat dipasarkan/ diperjual belikan.

\section{B. Faktor Penghambat Manajemen Kewirausahaan Di SD}

\section{Dari segi sarana prasarana}

Sarana prasarana belum sepenuhnya memenuhi masih terdapat beberapa alatalat dan bahan-bahan yang jumlahnya terbatas seperti koperasi sekolah memiliki tempat yang sempit, Kerajinan tangan alat dan bahan sering kali sulit didapatkan, Bercocok tanam alat yang digunakan masih terbatas karena terdapat banyak siswa di sekolah tersebut sehingga harus antri dalam menggunakan alat-alat bercocok tanam, pada penyewaan kantin masih terbatas yaitu meja makan untuk siswa seharusnya siswa duduk di meja makan khusus karena terbatasnya biaya maka siswa sering kali makan pada saat istirahat kurang teratur dan kurang rapi.

2. Biaya

Biaya atau anggaran yang dimiliki SDN 01 Nangsri masih terbatas dalam memenuhi kebutuhan kewirausahaan. Program kewirausahaan ini masih berkembang sehingga belum mendapatkan income yang begitu besar.

3. SDM/ Skill guru

Tidak semua guru mempunyai skill dan jiwa kemandirian untuk mengkaitkan dan menyisipi kewirausahaaan di dalam mata pelajaran yang diajarkan dengan menyisipkan kewirausahaan bagi siswa akan merangsang siswa untuk berfikir maju untuk berwirausaha. Hal ini lebih ditekankan pada siswa kelas atas.

4. Minat Anak

Kurangnya motivasi dan semangat siswa untuk aktif dalam kegiatan kewirausahaan. Hal ini karena tidak semua anak minat dengan entrakurikuler kewirausahaan yang diadakan.

5. Waktu

Kewirausahaan tidak dapat dilaksanakan karena terbentur waktu dengan acara rapat dan kegiatan kelas VI. Pada Ektrakurikuler dilaksanakan setelah jam 
sekolah. Terkadang siswa sudah merasa lelah untuk mengikuti ekstrakurikuler dan lebih memilih untuk pulang.

\section{Solusi dalam Mengurangi Hambatan Manajemen Kewirausahaan Di SD}

1. Dari segi sarana prasarana

Sarana prasarana yang kurang akan dilengkapi seiring berjalannya waktu pendapatan yang didapat dari hasil kewirausahaan. pada koperasi dengan menambahkan rak dan etalase gantung agar tempat yang dibutuhkan tidak terlalu banyak dan dapat menampung alat-alat yang dijual dikoperasi. Bercocok tanam dalam penggunaan pupuk dan alat sering kali dari swadaya masyarakat karena dilingkungan sekitar SDN terdapat pabrik pupuk sehingga dapat dimanfaatkan untuk mendukung aktivitas kewirausahaan. Pada kewirausahaan kerajinan tangan sebelum melakukan pelaksanaan pada siswa guru yang bertugas memberikan perencanaan sehingga bahan -bahan yang belum didapat guru yang lain dapat membantu mencarikan. Sedangkan untuk kantin yang sempit disiasati dengan pada saat istirahat siswa diminta untuk makan di teras sekolah. setiap kelas terdapat teras walau terkesan masih tidak rapi tapi hal ini dapat mengajarkan pada siswa agar makan dengan duduk dan tidak melakukan aktivitas yang lain.

2. Biaya

SDN 01 Nangsri mempunyai masalah biaya yang terbatas dalam mengembangkan kewirausahaan. Meskipun ada dana BOS, namun dana sekolah tersebut masih harus dibagi dengan yang lain untuk kebutuhan siswa dan kebutuhan sekolah sehingga untuk ekstrakurikuler jumlahnya terbatas. Hal ini pihak sekolah bekerja sama dengan komite untuk mencari dana bantuan dalam pengembangan sekolah.

3. SDM/Skill guru

Skill guru SDM yang berada di SDN 01 Nangsri tidak semua guru mau mengikuti kegiatan kewirausahaan. Hal ini peran kepala sekolah dalam melakukan pendekatan-pendekatan. Salah satunya dengan guru yang bersangkutan diajak untuk bertukar pendapat dimintai idea tau gagasan dan diberi tugas agar bertangung jawab untuk melakukan kewirausahaan dan menyisipkan pada saat mengajar didalam kelas.

4. Minat Anak

Menumbuhkan minat anak dalam berwirausaha selain didalam kelas dilingkup sekolahan biasanya. Kepala sekolah menyampaikan siswa-siswa yang mempunyai hasil karya yang bagus akan mendapatkan hadiah. Hadiah diberikan pada saat upcara selesai sehingga pada anak akan memberikan rasa yang bangga karena mendapatkan hadiah atas prestasi yang telah diraih selain itu dapat memotivasi teman-teman yang lain untuk lebih berprestasi dan menunjukan keahliannya.

5. Waktu

Waktu untuk kegiatan ekstrakurikuler memang terbatas yaitu pada saat pulang sekolah. Anak-anak terkadang sudah merasa capek. Hal ini disiasati pada saat jam olahraga, jam olahraga biasanya ada sisa hal ini dimanfaatkan untuk kegiatan ekstrakurikuler. Ini disepakati bersama anak dan guru penangung jawan dan guru yang yang piket.

Pengembangan kewirausahaan di SDN 01 Nangsri bukan hanya bekerja sama dengan pihak dalam sekolah akan tetapi juga bekerja sama dengan pihak luar sekolah yang dijembatani oleh komite sekolah komite sekolah berperan dalam menghubungkan antara masyarakat lingkungan perusahan daerah sekitar dan lainlain dalam pengembangan sekolah yang termasuk didalamnya program kewirausahaan. Kepala sekolah berperan sangat aktif untuk mencapai tujuan 
pengembangan kewirausahaan ini. beliau bertagung jawab penuh dalam mengembangakan dan mencapai tujuan dari kewirausahaan. Dengan adanya kegiatan kewirausahaan yang diadakan di SDN 01 Nangsri dapat menumbuhkan atau mengembangkan kecerdasasan finansial, kecerdasan emosional, kecerdasan intelektual, kecerdasan spiritual, dan kecerdasan adversity dalam diri para siswanya.

Hasil penelitian tersebut sejalan dengan teori menurut Santoso, dkk (2017) mengemukakan bahwa terdapat empat kecerdasan yang mendukung wirausaha yaitu kecerdasan finansial, kecerdasan emosional, kecerdasan sosial dan kecerdasan spiritual itulah yang akan mendukung bagaimana seorang wirausahawan mengatur usahanya guna memiliki kinerja yang tinggi.

Sementara itu, menurut Paristiwo (2013) Sosok wirausaha yang memiliki Entre- $Q$ selain memiliki kelebihan dalam cara berpikir, akan tetapi juga cerdas secara emosi dan cerdas dalam hal spiritualitas. Entre- $Q$ dapat dikembangkan dengan memperbanyak pengalaman serta praktik.

Dari beberapa pendapat diatas, maka dapat dikatakan bahwa kecerdasan kewirausahaan yang harus dimiliki yaitu melingkupi kecerdasan Finansial (FQ), Kecerdasan Intelektual(IQ), Kecerdasan Emosional (EQ), Spiritual Quotient (Kecerdasan Spiritual), dan Kecerdasan Advertisy (AQ). Kecerdasan-kecerdasan tersebut dapat dimiliki dan ditumbuh kembangkan dalam diri siswa melalui berbagai kegiatan kewirausahaan yang diadakan di sekolah.

\section{SIMPULAN}

Kegiatan kewirausahaan di SDN 01 Nangsri lebih menekankan pada kreativitas siswa dengan menggunakan bahan-bahan yang ramah lingkungan. Karena SDN 01 Nangsri merupakan sekolah rintisan Adiwiyata siswa diajarkan untuk membuat hasil karya yang berbahan ramah lingkungan yang dapat didaur ulang sehingga dapat menghasilkan suatu karya yang dapat diperjual belikan dapat memberikan pemasukan pada peserta didik dan dapat dimanfaatkan sebagai sumber dana untuk mengembangkan karya yang lain sehingga dapat berkembangkan bervariasi. Pada acara-acara adiwiyata biasanya hasil karya sisswa dapat dipamerkan dan diperjual belikan. Hasil-hasil karya siswa selain diperjual belikan di koperasi sekolah juga dipajang di etalase sekolah sebagai bentuk apresiasi kepada siswa.

Pengembangan kewirausahaan di SDN 01 Nangsri bukan hanya bekerja sama dengan pihak dalam sekolah akan tetapi juga bekerja sama dengan pihak luar sekolah yang dijembatani oleh komite sekolah komite sekolah berperan dalam menghubungkan antara masyarakat lingkungan perusahan daerah sekitar dan lain-lain dalam pengembangan sekolah yang termasuk didalamnya program kewirausahaan. Kepala sekolah berperan sangat aktif untuk mencapai tujuan pengembangan kewirausahaan ini. beliau bertagung jawab penuh dalam mengembangakan dan mencapai tujuan kewirausahaan disekolahnya. Kepala sekolah telah menerapkan kecerdasankecerdasan kewirausahaan sehingga kewirausahaan yang ada disekolah tersebut dapat berjalan optimal.

\section{DAFTAR PUSTAKA}

Alma, Buchari. (2011).Kewirausahaan Untuk Mahasiswa Umum.Alfabeta: Bandung Frinces, Z. H. (2011).Kepemimpinan Berbasis Kewirausahaan. Jogjakarta: Media Pustaka.

Paristiwo, H. 2010.Entrepreneurial Quotient (Entre-Q):Kecerdasan Wirausaha. IAIN Sultan Maulana Hasanudin Banten

Santoso, R., Candraningrat,. Binawati, L. (2017). Elemen Kecerdasan Wirausaha Untuk Meningkatkan Kinerja Industri Kecil dan Menegah(IKM.) 
Miles, M. \& Huberman, A. M. (200)7. Analisis Data Kualitatif: Buku Sumber Tentang Metode- Metode Baru. Jakarta: Universitas Indonesia Press.

Undang-Undang Republik Indonesia Nomor 20 Tahun 2003 Tentang Sistem Pendidikan Nasional

Departemen Pendidikan Nasional tahun 2013

Drucker, P. F. (1985). Innovation and Entrepreneurship. New York: Harper \& Row.

Dean, J. \& Sharfman, M. (1996). Does Decision Process Matter? A Study of Strategic Decision-Making Effectiveness. Academy of Management Journal, Vol. 39, No. 2,.368-396..

Samino. (2012). Manajemen Pendidikan Spirit Keislaman dan Keindonesiaan. Surakarta: Muhammadiyah University Press. 